\title{
1. Introduction: the surveillance, security and privacy paradox
}

\section{INTRODUCTION}

In his dystopian novel Nineteen Eighty-Four, ${ }^{1}$ published in 1949, George Orwell predicted a world in which the ruling class was in almost complete control of information and expression. The book epitomized political oppression and influenced millions, with phrases such as 'Big Brother' and 'doublethink' becoming synonymous with totalitarianism, the surveillance state and the power of mass media to manipulate public opinion, to rewrite history and even the truth. ${ }^{2}$ Seven decades later, the world of fiction so vividly portrayed by Orwell seems to have become an all-pervasive reality in most societies, including liberal democracies, dominated by cyber technologies exploited by government and non-government actors alike. This to a large extent is the result of the 'digital revolution' of the late twentieth and early twenty-first centuries, which has profoundly affected almost every aspect of human activity, allowing for information exchange, access and sharing at heretofore unprecedented scale and speed. The birth of the Internet in particular has altered practically beyond recognition the manner in which individuals around the globe conduct their work-related, social and consumer activities, together with how they interact with public services and institutions. These seemingly irreversible changes in communications have been accompanied by significant advances in states' intelligence-gathering ${ }^{3}$ activities.

\footnotetext{
George Orwell, Nineteen Eighty-Four (Penguin Books, 1949).

Jonathan Freeland, '1984 by George Orwell, Book of a Lifetime: An Absorbing, Deeply Affecting Political Thriller', The Independent (2 July 2015).

3 US Department of Defense (DoD), Dictionary of Military and Associated Terms (as of June 2020) 107 ('US DoD Dictionary'). The US DoD defines 'intelligence' as: '(1) the product resulting from the collection, processing, integration evaluation, analysis, and interception of available information concerning foreign nations, hostile or potentially hostile forces or elements or areas of actual or potential operations; (2) the activities that result in the product; (3) the organizations engaged in such activities.'
} 
The origins of collecting signals intelligence (SIGINT) ${ }^{4}$ can be traced to the advent of the telegraph. Developed in the 1830s and 1840s by Samuel Morse, among others, the telegraph revolutionized long-distance communications by transmitting electronic signals over a wire laid between stations. ${ }^{5}$ Telegraphic transmissions became recognized as public property and thus, once they entered the public domain, were perceived as open and available for anyone to detect and collect. ${ }^{6}$ Today, SIGINT forms a vital part of states' foreign policy decision making. Indeed, as acknowledged by the United States' (US) Central Intelligence Agency (CIA): 'world leaders communicate with their people in a variety of ways. All of these forms of communication emit a signal that can be collected. The information gathered from these intercepted signals is of vital importance to national security."

In recent decades, intelligence agencies ${ }^{8}$ around the globe have developed sophisticated methods of accumulating vast amounts of data transmitted over the Internet, the analysis of which became possible by technological advancements in algorithmic and related computer analysis. Equally, the increased capacity to store information, coupled with the decreased costs of such retention, transformed methods of data acquisition, examination and

4 'SIGINT' is 'intelligence derived from electronic signals and systems used by foreign targets, such as communication systems, radars, and weapons systems. SIGINT provides a vital window for our nation into foreign adversaries' capabilities, actions, and intentions' - see National Security Agency/Central Security Service, 'Signals Intelligence', www.nsa.gov/what-we-do/signals-intelligence.

5 History, 'Morse Code and the Telegraph' (6 June 2019), www.history.com/ topics/inventions/telegraph.

6 For example, the British Government Code and Cypher School was established in 1919 and played a major role during the Second World War, when it was based at Bletchley Park. The 'ultra-intelligence' produced at Bletchley Park through regular breaking of the secret communications of the Axis Powers, especially through its Enigma and Lorenz cipher machines, possibly reduced the length of the Second World War by four years. The name of the organization was changed to Government Communications Headquarters in 1946 and it is now based in Cheltenham, Gloucestershire - see John Ferris, Behind the Enigma: The Authorized History of GCHQ, Britain's Secret Cyber-Intelligence Agency (Bloomsbury Publishing Plc, 2020); see also Glenn Sulmasy and John Yoo, 'Counterintuitive: Intelligence Operations and International Law' (2007) 28(3) Michigan Journal of International Law 625-38, 631.

7 US CIA, 'News and Information. INTelligence: Signals Intelligence' (30 April 2013), www.cia.gov/news-information/featured-story-archive/2010-featured-storyarchive/intelligence-signals-intelligence-1.html.

8 US DoD Dictionary (n 3) 107. There is no universal definition of 'intelligence agencies'; however, the US DoD Dictionary refers to 'intelligence community' and defines it as '[a]ll departments or agencies of a government that are concerned with intelligence activity, either in an oversight, managerial, support, or participatory role'. 
sharing. These activities became collectively known as 'mass surveillance', the ubiquity of which is usually justified by the need of states to protect themselves from internal and external threats emanating from complex forms of terrorism and serious crime. However, the indiscriminate collection and retention of enormous volumes of digital communications, foreign and domestic alike - as first exposed in 2013 by Edward Snowden - present a paradox. This is because such information may be of value to security agencies while concurrently posing a serious risk to individuals' rights - in particular, by eroding and undermining the right to privacy of communications. At the heart of this conundrum is the conviction, evidenced by the policy stance of many governments, that greater surveillance and bulk collection of communications lead to greater security. ${ }^{9}$ However, the weakness of this argument is the danger that if there are any benefits to societies - and by extension, to the international community - in terms of safeguarding peace and security, these are inevitably outstripped by the sacrificing of individuals' fundamental rights and freedoms to achieve these goals. This creates a tension between proponents of greater securitization on the one hand and civil liberties advocates on the other.

This chapter explores this traction. It consists of eight sections. Section 2 engages with some aspects of global and national security, outlining their respective goals and identifies contemporary threats. Section 3 defines mass surveillance of communications and highlights some of the means and methods that governments deploy to assist in achieving their security goals, including the programs used and intelligence-sharing agreements among state agencies. Section 4 considers a number of challenges that this presents to the protection of human rights, focusing on the right to privacy in the digital age and discusses numerous responses to the problem in the years that followed the Snowden disclosures from the United Nations (UN) and outside of its institutions. Section 5 reviews current trends in state led mass surveillance. This is then followed by a discussion of the security, privacy and surveillance paradox in section 6. Section 7 circumscribes the books' aims, while its scope is outlined in section 8 .

9 This is indicated in, for example, the statement of former UK Home Secretary Theresa May when introducing the Investigatory Powers Bill to the House of Commons in 2015 - see Matt Burgess, 'Investigatory Powers Bill: What Is It and What Does It Mean', Wired (4 November 2015), www.wired.co.uk/article/surveillance-bill -government-internet-history. 


\section{SECURITY}

'Security' means 'the state of being secure, especially from danger or attack' ${ }^{10}$ This term encompasses a plethora of meanings, including global, national, human, environmental, economic and, most recently, cyber security. ${ }^{11}$ There is no single agreed definition, but two useful descriptions of this term are those of the Council of the European Union (EU) and the UN. Thus, according to the former, 'security' denotes 'protecting people and the values of freedom and democracy, so that everyone can enjoy the daily lives without fear'; ${ }^{12}$ while the latter sees this concept as 'the preservation of the norms, rules, institutions and values of society'. ${ }^{13}$ Accordingly, all institutions, principles and structures associated with a society - including its people - are to be protected from 'military and non-military threats' ${ }^{14}$ While national security is the ability of a state to cater for the protection and defence of its citizenry, ${ }^{15}$ global security:

evolved from the necessity that nature and many other activities, particularly globalization, have placed on States. These are demands that no national security apparatus has the capacity to handle on its own and, as such, call for the cooperation of States. ${ }^{16}$

It has been suggested that the nature of the challenges to the international community is such that nations' security concerns are deeply interconnected, to the extent that one state's safety needs cannot realistically be evaluated without taking into consideration those of other countries. ${ }^{17}$ This in turn breeds rivalry among states, which can be remedied only through their cooperation in global

10 Bryan A Garner, Black's Law Dictionary (West Group, 1999) 1358.

11 The UK National Cyber Security Centre (NCSC) states that 'cyber security' is 'how individuals and organizations reduce the risk of cyberattack. Cyber security's main function it to protect the devices we all use (smartphones, laptops, tablets and computers) and the services we access -both online and at work- from theft or damage. It's about preventing unauthorised access to the vast amounts of personal information on these devices and online' - see UK NCSC, 'What is Cyber Security?', www.ncsc .gov.uk/section/about-ncsc/what-is-cyber-security.

12 Council of the European Union, Internal Security Strategy for the EU, Towards a European Security Model (March 2010) 12.

13 See Samuel M Makinda, 'Sovereignty and Global Security' (1998) 29(3) Security Dialogue 281-92 in Segun Osisanya, 'National Security Versus Global Security', UN Chronicle (October 2014), https://unchronicle.un.org/article/national-security-versus -global-security.

$\begin{array}{ll}{ }_{14} & \text { Ibid. } \\ { }_{15} & \text { Ibid. } \\ { }_{16} & \text { Ibid. } \\ { }_{11} & \text { Ibid. }\end{array}$ 
security initiatives. ${ }^{18}$ In short, the global character of the various security challenges requires international responses and cooperation.

States must not only identify current and future threats to national security, but also construct effective strategies to deal with them, as they are many and varied. Some of the issues that decision makers must deal with on a national level are counter-terrorism, together with serious and organized crime (such as child sexual exploitation; fraud; money laundering and other economic crimes; bribery; modern slavery and cyber crime). For example, the United Kingdom (UK) government set out in its 2010 National Security Strategy ${ }^{19}$ 15 main security risks, of which four have been and continue to be classed as of highest priority: (1) international terrorism, including through the use of chemical, biological, radiological and nuclear materials, together with terrorism relating to Northern Ireland; (2) cyber attacks, including by other states, organized crime and terrorists; (3) international military crises between states; and (4) major accidents or natural hazards. ${ }^{20}$ The nation's safety is a government's primary responsibility, and the potential for large-scale harm caused by hostile actions is often neither tangible nor immediate. In the UK, for example, in 2019 the terrorist threat level was described as 'large and multi-faceted' - a classification which took into account (among other acts of criminality) the 2017 London and Manchester attacks, which claimed the lives of 36 innocent people. ${ }^{21}$ However, although the menaces to national defence are becoming more complex, unpredictable and alarming, they must be viewed in perspective. Thus, as observed by the independent reviewer of terrorist legislation, David Anderson QC, in his 2015 report A Question of Trust, ${ }^{22}$ it would be a mistake to describe the current danger level as 'unprecedented', as events capable of taking life on a massive scale (eg, the Black Death) ${ }^{23}$ are a feature of every age, while some threats will simply not be realized. ${ }^{24}$ Therefore, although the challenges to national security must not be ignored, 'claims of

\footnotetext{
18 Ibid.

19 HM Government, A Strong Britain in an Age of Uncertainty: The National Security Strategy (October 2010) Cm 7953. The Strategy is updated and reviewed annually.

20 Ibid 28-31. See also HM Government, National Security Strategy and Strategic Defence and Security Review 2015: Third Annual Review (July 2019) para 1.8.

$21 \quad$ Ibid 12.

22 David Anderson, A Question of Trust. Report of the Investigatory Powers Review (June 2015) ('Anderson').

23 Ibid 39. It is estimated that the Black Death may have killed at least one-third of Europe's population in the years after 1346.

24 Ibid.
} 
exceptional or unprecedented threat level - particularly for the purposes of curbing well-established liberties - should be approached with scepticism' ${ }^{25}$

Governments respond to national security concerns through, among other means, the use of covert investigatory methods, of which the routine monitoring of electronic communications is a central and growing part. ${ }^{26}$ These powers encompass a range of methods, such as direct and intrusive surveillance (tailing, bugging); property interference; the use of covert human intelligence; surveillance cameras; and DNA databases. ${ }^{27}$ This spectrum of practices involves 'communications surveillance', defined as 'the monitoring, intercepting, collecting, obtaining, analysing, using, preserving, retaining, interfering with, accessing or similar actions taken with regard to information that includes, reflects, arises from or is about a person's communications in the past, present or future' ${ }^{28}$

That states' investigatory powers are now routinely exercised on a previously unprecedented scale was exposed in 2013 by Edward Snowden, with the publication of documents removed from the US National Security Agency (NSA). These revealed an array of activities, including: (1) bulk interception of communications and collection of Internet and international communications data; (2) tools for advanced searching and analysis of intercepted data; (3) cooperative relationships between governments and telecommunications service providers; and (4) intelligence sharing. ${ }^{29}$ This mass collection, retention and examination of communications contents and metadata has been the leading source of controversy ever since the Snowden disclosures and is outlined next.

\section{MASS SURVEILLANCE}

'Mass surveillance' can be defined as the indiscriminate monitoring of the population or a significant component of a group of persons. ${ }^{30}$ In recent decades, it has become one of the preponderant methods of intelligence col-

25 Ibid 40.

26 Office of the UN High Commissioner for Human Rights (OHCHR), 'The Right to Privacy in the Digital Age. Report of the United Nations High Commissioner for Human Rights' (30 June 2014) UN Doc A/HRC/27/37 47 ('A/HRC/27/37’).

27 Anderson (n 22) 19.

28 International Principles on the Application of Human Rights to Communications Surveillance, Necessary and Proportionate (10 July 2013) 13 ('Necessary and Proportionate').

$29 \quad$ Anderson (n 22) 125.

30 Privacy International, Mass Surveillance, https://privacyinternational.org/learn/ mass-surveillance\#: : text=Mass\%20surveillance $\% 20$ involves $\% 20$ the $\% 20$ acquisition ,they\%20are\%20suspected\%20of\%20wrongdoing ('Mass Surveillance’). 
lection. This type of information gathering takes place without prior suspicion or a specific query and can be distinguished from targeted surveillance, which is directed towards individuals or organizations of interest. ${ }^{31}$ In essence, mass interception of communications has a proactive element, aimed at identifying future dangers, rather than investigating known threats. ${ }^{32}$

As discussed in Chapter 2, there are a number of designations adopted by various UN bodies, regional institutions and courts to describe these practices, such as 'online surveillance', 'bulk interception' and 'strategic surveillance'. This book adopts the term 'mass surveillance' as an umbrella expression that encompasses general, large-scale interception and collection of communications through technical means in cyberspace.

\subsection{Mass Surveillance: Means and Methods}

The tools for conducting mass surveillance are many and varied. With advancements in digital science, they can be developed and deployed relatively quickly. This at least to some extent explains why the law (domestic and international) lags behind the rapidly developing technologies of surveillance and does not always allow for an adequate response to the resultant changes.

Broadly speaking 'digital surveillance' comprises: (1) bulk data interception - that is, the interception, collection and storage of content and metadata contained in packets that travel through several Internet exchange points (a well-known example discussed in this book is the tapping of undersea fibre-optic cables); (2) Internet communication technology monitoring, which focuses on human activity on social media platforms such as Twitter, Facebook and Instagram and peer-to-peer communications tools such as WhatsApp, analysing content (the text of the message), metadata (its time, location, duration) and network responses ('follow', 'friends', 'retweet' and 'like' patterns); (3) geolocation and remote sensing, which relate to closed-circuit television monitoring, mobile device signals and global positioning systems data; (4) biometrics, which involves the tracking of unique biometric identifiers such as facial/ retinal recognition, voice recognition, skin reflection and thermograms; (5) and Internet of Things (IoT), a term that describes consumer devices that are controlled through Internet-enabled applications and allows for the collection

31 EU Agency for Fundamental Rights, 'Surveillance by Intelligence Services. Fundamental Rights Safeguards and Remedies in the EU. Volume II: Field Perspectives and Legal Update' (Luxembourg Publications Office of the EU, 2017).

32 Council of Europe Thematic Factsheet, Mass Surveillance (August 2017), https://rm.coe.int/factsheet-on-mass-surveillance-corrected-and-final-rev2august2017/ 1680736031. 
of data on individuals' behavioural indicators, such as time spent at home or at work, speech detection, together with purchasing and consumption patterns. ${ }^{33}$

\subsubsection{Bulk data interception}

This book is predominantly focused on the first of the aforementioned methods of mass surveillance - that is, bulk data interception. Some of the best-known computer systems that this book makes frequent references to are PRISM ${ }^{34}$ and Tempora, ${ }^{35}$ the use of which was first revealed on 6 June 2013 by British newspaper The Guardian. ${ }^{36}$ The allegations pertaining to the US and UK security services' use of these interception methods came to the fore following Edward Snowden's exposure of the global clandestine interception and gathering of communications conducted by the NSA and its Five Eyes partner agencies: the UK Government Communications Headquarters (GCHQ); Canada's Communications Security Establishment Canada (CSEC); Australia's Australian Signals Directorate; and New Zealand's Government Communications Security Bureau. ${ }^{37}$ The subsequent inquiry into the extent of these practices by, among others, the Council of Europe $(\mathrm{CoE})$ - published in 2015 report titled Mass Surveillance ${ }^{38}$ - confirmed a 'stunning array' of means and methods of collecting, storing and sharing data by intelligence and law enforcement agencies around the globe. ${ }^{39}$

The report confirmed the existence in several countries of 'surveillance-industrial complex ... fostered by the culture of secrecy sur-

33 Akin Üner, Politics of Digital Surveillance, National Security and Privacy (Centre for Economic and Foreign Policy Studies, 2018) 5-6.

34 Anderson (n 22) 330. Under the PRISM program, first authorized by the then US President Bush following the attacks of 11 September 2001, the NSA can collect private data such as emails, chats, videos, photos, stored date and online social networking details from servers of nine US Internet companies (the so-called 'PRISM providers'): Microsoft, Yahoo, Google, Facebook, PalTalk, AOL, Skype, YouTube and Apple.

35 Ibid. Tempora has been allegedly operated since 2011 by UK GCHQ and involves the attachment of intercept probes to transatlantic fibre-optic cables located on British soil, which carry data to Western Europe from telephone exchanges and Internet servers in North America. This provides analysts with data from all email, web and social chats.

36 Glen Greenwald, 'NSA Collecting Phone Records of Millions of Verizon Customers Daily', The Guardian (6 June 2013).

37 Privacy International, Eyes Wide Open. Special Report (26 November 2013) ('Eyes Wide Open').

$38 \mathrm{CoE}$, Committee on Legal Affairs and Human Rights, 'Mass Surveillance. Explanatory Memorandum by Mr Pieter Omtzigt, Rapporteur' (26 January 2015) ('CoE Mass Surveillance Memorandum').

39 Ibid. 
rounding surveillance operations [and] their highly technical character' ${ }^{40}$ The methods of surveillance listed by the $\mathrm{CoE}$ include the acquisition of internet companies' customer data by the 'front door' - as is the case with PRISM, which enables direct access to data from nine Internet firms, including Google, Microsoft and Yahoo. ${ }^{41}$ The program is said to be the biggest single contributor to the NSA's current intelligence collection efforts. In addition, the agencies have 'back-door access', whereby data from these companies is intercepted without their knowledge via systems such as MUSCULAR. ${ }^{42}$ Furthermore, the UK and the US have tapped into fibre-optic cables carrying global communications, made possible since the relevant physical infrastructure (switches, routers, servers and cables) is located in their territories. ${ }^{43}$ Reportedly, in this way GCHQ:

has been able to access at least 200 fibre optic cables, giving the agency a capability to monitor up to 600 million communications every day [with the ability to allegedly store] internet and phone use data up to 30 days in order for it to be sifted and analysed. ${ }^{44}$

The intelligence agencies are also said to be involved in the collection of metadata (often referred to as 'communications data') - that is, 'information about the time and location of a phone call or email, as opposed to the content of these conversations or messages ${ }^{\prime 45}$ - thus allowing them to compile a more accurate and detailed profile of a person than through accessing the content of these communications alone. ${ }^{46}$ For example, in March 2013, the NSA allegedly amassed up to 97 billion pieces of metadata from computer networks worldwide. ${ }^{47}$

In addition, the security services have been able to access phone text messages and phone calls through such programs as DISHFIRE, which in April 2011 was shown to collect on average 194 million text messages a day, enabling the NSA to gain information on people's travel plans, contact lists and financial transactions, including from individuals not suspected of any illegal activities. ${ }^{48}$ The NSA has also developed MYSTIC, a voice inter-

\footnotetext{
40 CoE, Committee on Legal Affairs and Human Rights, 'Mass Surveillance. Draft Resolution' (2015) AS/Jur 2 ('CoE Mass Surveillance Resolution').

${ }_{41}$ CoE Mass Surveillance Memorandum (n 38) para 10.

42 Ibid.

43 Ibid para 11.

44 Ibid.

45 Ibid para 12.

46 Ibid.

47 Ibid para 13.

$48 \quad$ Ibid para 15.
} 
ception program designed 'to gather mobile calls placed in countries with a combined population of more than 250 million people'. ${ }^{49}$ It has enabled the US to record every single phone call in the Bahamas (on the basis of an operation codenamed SOMALGET) without the knowledge or consent of that country's government, processing approximately 100 million calls per day. ${ }^{50}$ Additionally, the NSA can retrospectively listen to previously recorded phone calls in order to 'figure out what targets said during calls that occurred even before the targets were identified as such', using, among others, the RETRO program. ${ }^{51}$ This array of surveillance techniques is further enhanced by the intelligence agencies' ability to amass millions of facial images, fingerprints and other identifiers from emails and other communications. Reportedly, one of the boldest efforts of the NSA to obtain facial images is through its WELLSPRING program, which collects them from the Internet and uses them to track suspected terrorists and other intelligence targets. ${ }^{52}$ These investigatory techniques are supported by both the US government and the private sector investing heavily in facial recognition research and development.

\subsubsection{Intelligence-sharing arrangements}

In conjunction with these methods of gathering information, intelligence sharing has become one of the main methods of cooperation in the effort to combat international terrorism and organized crime. It occurs in various ways and includes accessing 'raw' (unanalysed) information, such as Internet traffic intercepted in bulk from fibre-optic cables by other security organs; obtaining data stored in databases held by other governments or jointly managed with other countries; and receiving already analysed information, usually in the form of an intelligence report. ${ }^{53}$ It also consists of operational cooperation, facilities and equipment hosting, training and capacity building, together with technical and financial support. ${ }^{54}$

These practices have significantly intensified since the 11 September 2001 attacks on the US (' $9 / 11$ attacks'). Indeed, such intergovernmental bodies as the North Atlantic Treaty Organization (NATO) have made every effort to increase consultation on terrorism and related issues among their member and

\footnotetext{
Ibid para 16.

Ibid.

Ibid para 17.

Ibid para 19.

53 Privacy International, Secret Global Surveillance Networks: Intelligence Sharing Between Governments and the Need for Safeguards (April 2018) 5 ('Secret Surveillance
} Networks').

54 Ibid. 
non-member countries. ${ }^{55}$ This global collaboration has been underpinned by the UN's explicit recognition of the need for a common strategic and operational approach of the international community on security and related matters. It has thus recommended that practical steps be taken to individually and collectively prevent and combat the terrorist threat. As a result of this policy stance, in 2006 the UN adopted the Global Counter Terrorism Strategy, ${ }^{56}$ a unique instrument to enhance national, regional and international efforts to counter terrorism. ${ }^{57}$ The Strategy comprises a resolution ${ }^{58}$ and an action plan consisting of four pillars, one of which propagates 'measures to build States' capacity to prevent and combat terrorism and to strengthen the role of the United Nations system in this regard' ${ }^{59}$ The document thus recognizes that such capacity building in all states is a core element of the global counterterrorism effort and consequently encourages states and relevant international, regional and sub-regional organizations to work closely together, 'including by sharing information, with all bilateral and multilateral technical assistance providers' ${ }^{60}$ At the same time, it recognizes and stresses the need for states 'to ensure respect for human rights for all and the rule of law as the fundamental basis of the fight against terrorism'. ${ }^{61}$

Intelligence sharing usually occurs pursuant to intelligence-sharing agreements. Although it is impossible to provide a complete account, one of the best-known co-operations is the Five Eyes alliance pursuant to the UKUSA Signals Intelligence Agreement, ${ }^{62}$ first entered into by the UK and the US in 1946 and later extended to Australia, New Zealand and Canada. However, very little is known outside the intelligence community regarding what exactly it presently comprises. It has purportedly given the Five Eyes partners much

55 NATO Multimedia Library, 'Intelligence/Information Sharing in Combating Terrorism' (16 May 2019), www.natolibguides.info/intelligence.

56 UN Office of Counter Terrorism, UN Global Counter Terrorism Strategy (2006) ('UN Counter Terrorism Strategy'). The Sixth Review of the UN Global Anti-Terrorism Strategy took place on 26 June 2018, followed by UNGA Resolution, 'The UN Global Counter Terrorism Review' (2 July 2018) UN Doc A/Res/72/284.

57 Ibid.

58 UNGA Resolution, 'The United Nations Global Counter-Terrorism Strategy' (20 September 2006) UN Doc A /Res/60/288 ('A/Res/60/288').

59 UN Counter Terrorism Strategy (n 56). The other three pillars are: (1) 'measures to address the conditions conducive to the spread of terrorism'; (2) 'measures to prevent and combat terrorism'; and (3) 'measures to ensure respect for human rights for all and the rule of law as the fundamental basis of the fight against terrorism'.

${ }^{60}$ Ibid part III para 6.

61 Ibid part IV.

62 British-US Communications Intelligence Agreement (5 March 1946), www.nsa .gov/Portals/70/documents/news-features/declassified-documents/ukusa/agreement _outline_5mar46.pdf. 
wider scope of operations besides sharing primary signals intelligence and enables their security services to intercept, collect, analyse and decrypt intelligence information. ${ }^{63}$ An example of this collaboration is ECHELON, a global network operated with the primary aim of intercepting private and commercial (rather than military) communications and purportedly capable of intercepting any 'telephone, fax, internet, or email message sent by any individual' ${ }^{64}$

The UKUSA Agreement is said to assign the responsibility for surveillance to various partners by allocating them the 'interception rights' in specific parts of the globe. ${ }^{65}$ Thus, the UK zone of operations includes Africa and Europe, together with the region east of the Ural Mountains; ${ }^{66}$ Canada's covers the north latitudes and the Polar regions; while Australia's and New Zealand's extends to Oceania and the South Pacific respectively. ${ }^{67}$ Since 1946, the web of intelligence sharing has unsurprisingly evolved beyond the original UKUSA Agreement and now includes the Five Eyes acting in collaboration with other intelligence agencies on the basis of a variety of arrangements, such as SIGINT Seniors Europe (the Five Eyes plus Belgium, Denmark, France, Germany, Italy, the Netherlands, Norway, Spain and Sweden); ${ }^{68}$ SIGINT Seniors Pacific (the Five Eyes plus India, Singapore, South Korea and Thailand); ${ }^{69}$ the Nine Eyes (the Five Eyes plus Denmark, France, the Netherlands and Norway); $;^{70}$ the Fourteen Eyes (the Nine Eyes plus Belgium, Germany, Italy, Spain and Sweden) ${ }^{71}$ and the Forty Three Eyes (the Fourteen Eyes plus the 2010 members of the International Security Assistance Forces to Afghanistan). ${ }^{72}$ Apart from these methods of cooperation, there are a number of equally secretive bilateral and multilateral agreements in other regions of the globe - such as the Club of Berne (an intelligence-sharing arrangement among the EU intelligence services) and the Shanghai Cooperation Organizations (an affiliation among the People's Republic of China ('China'), India, Kazakhstan, Kyrgyzstan, Pakistan, the Russian Federation ('Russia'), Tajikistan and Uzbekistan) together with intelligence exchange arrangements within a group of states comprising Russia, Iraq, Iran and Syria to facilitate the fight against the Islamic State. ${ }^{73}$

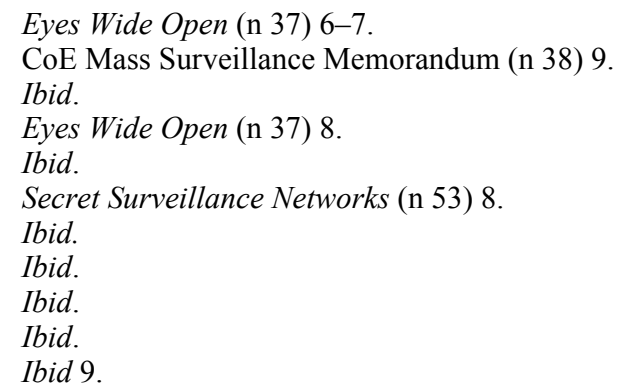


Intelligence sharing has thus become one of the most pervasive, yet least regulated surveillance practices in the modern world. ${ }^{74}$ At least one report based on an international collaborative investigation carried out in 2018 by 40 non-governmental organizations (NGOs) in 42 countries found 'alarming weaknesses in the oversight arrangements that are supposed to govern the sharing of intelligence between State intelligence agencies' ${ }^{75}$ The UN Human Rights Committee (HRC) - a body of independent experts that monitors the implementation of the International Covenant on Civil and Political Rights 1966 (ICCPR $)^{76}$ by its states parties ${ }^{77}$ - has recognized that intelligence sharing prima facie constitutes an interference with the right to privacy, and expressed concerns about insufficient safeguards against arbitrary interference with that right with regard to the sharing of raw data. ${ }^{78}$ Particularly problematic in this context is the intelligence services' ability to 'outsource' surveillance to other agencies, thus bypassing domestic restrictions on intelligence gathering by relying on allied services to obtain and then share information on their own nationals. ${ }^{79}$ Such practices have been termed 'collusion for circumvention' ${ }^{80}$ This entails using relationships with foreign partners to access information that the agency either could not lawfully gain or would find it difficult to obtain due to domestic legal constraints regarding, for example, the types of techniques used to conduct the surveillance, or generally its ability to perform such activities on its own citizens. ${ }^{81}$ Thus, it has been confirmed that GCHQ and the NSA 'may exploit their relationship to acquire information that would be more difficult to obtain lawfully themselves within their own jurisdictions' ${ }^{82}$

$74 \quad$ Ibid 3.

75 Ibid.

76 UNGA, International Covenant on Civil and Political Rights (adopted 16 December 1966, entered into force 23 March 1976) 999 UNTS 999, 171 ('ICCPR').

77 OHCHR, 'Human Rights Committee. Monitoring Civil and Political Rights', www.ohchr.org/en/hrbodies/ccpr/pages/ccprindex.aspx.

78 See UNHRC, 'Concluding Observations on the Seventh Periodic Report of Sweden' (28 April 2016) UN Doc CCPR/C/SWE/CO/7 paras 36-37; UNHRC, 'Concluding Observations on the Initial Report of Pakistan' (23 August 2017) UN Doc CCPR/C/PAK/CO/1 para 35; UNHRC, 'Concluding Observations on the Seventh Periodic Report of the United Kingdom of Great Britain and Northern Ireland' (17 August 2015) UN Doc CCPR/C/GBR/CO/7 para 24 ('Concluding Observations, UK'). 79 See Hans Born, Ian Leigh and Aidan Wills, 'Making International Intelligence Cooperation Accountable' (21 May 2015) Norwegian Parliamentary Oversight Committee 48-50 ('Born et al').

80 CoE Mass Surveillance Memorandum (n 38) paras 30-31.

81 Born et al (n 79). See also CoE Mass Surveillance Memorandum (n 38).

82 UK Hansard, 10 June 2013, Cols 34, 35 and 39. 
Commenting on this issue, the UN High Commissioner for Human Rights (OHCHR), in her 2014 report, observed that there is:

credible information to suggest that some Governments systematically have routed data collection and analytical tasks through jurisdictions with weaker safeguards for privacy. Reportedly some Governments have operated a transnational network of intelligence agencies through interlocking legal loopholes, involving the coordination of surveillance practices to outflank the protection provided by domestic legal regimes. ${ }^{83}$

Indeed, in the aftermath of the Snowden exposés and partly as a result of them, both the UN General Assembly (UNGA) and the UN human rights treaty bodies have begun to pay very close attention to this and various other forms of state surveillance, and how these implicate international law. Particular emphasis has been placed on their impact on the right to privacy of communications, thrusting this right firmly into the limelight in various international forums.

\section{PRIVACY}

Privacy is a complex and multifaceted concept, difficult to encapsulate in a neat definition. However, in essence, it is 'the presumption that individuals should have an area of autonomous development, interaction and liberty free from State intervention and excessive unsolicited intrusion by other uninvited individuals' ${ }^{84}$ International human rights law $^{85}$ expressly recognizes privacy as a fundamental right. It is thus enshrined in a number of international instruments, including in Article 12 of the Universal Declaration of Human Rights 1948 (UDHR) ${ }^{86}$ and Article 17 of the International Covenant on Civil and Political Rights $1966 .{ }^{87}$ It is also stipulated in numerous regional treaties

$83 \mathrm{~A} / \mathrm{HRC} / 27 / 37$ (n 26) para 30.

84 UNGA, 'Report of the Special Rapporteur on the Promotion and Protection of Human Rights and Fundamental Freedoms While Countering Terrorism, Ben Emmerson' (23 September 2014) UN Doc A/69/397 para 28 ('A/69/397').

85 Yuval Shany, 'Cyberspace: The Final Frontier of Extra-Territoriality in Human Rights Law' (26 September 2017) HUJI Cyber Security Research Blog, https:// csrcl.huji.ac.il/people/cyberspace-final-frontier-extra-territoriality-human-rights-law. Writing in the context of states' extra-territorial obligations in cyberspace, Shany describes international human rights law as a 'legal hybrid' - that is, 'a system of norms and institutions that channels universal norms through the apparatus of the state system'.

86 Universal Declaration of Human Rights (adopted 10 December 1948) UNGA Res 217 A(III) Art 12 ('UDHR').

87 ICCPR (n 76) Art 17. 
- in particular, Article 8 of the European Convention on Human Rights 1950 $(\mathrm{ECHR})^{88}$ and Article 11 of the American Convention on Human Rights 1969 (ACHR). ${ }^{89}$ This normative framework is enhanced by a large body of jurisprudence that has contributed to the interpretation of this right by the HRC, various UN human rights mandate holders and regional human rights courts - in particular, the European Court of Human Rights (ECtHR), where a sizeable body of case law pertaining to privacy protection in the context of state surveillance has been amassed. The post-Snowden years have seen a number of important developments in this regard, both within and outside the UN.

\subsection{The Right to Privacy in the Digital Age at the UN}

Since 2013, the UNGA and the Human Rights Council - an inter-governmental organization made up of $47 \mathrm{UN}$ member states responsible for strengthening the protection of human rights around the globe and for addressing and making recommendations in relation to their violations ${ }^{90}$ - have paid particular attention to the right to privacy in the digital age. Previously, however, privacy rights seem to have been given scant attention by the UN human rights institutions. Some commentators even contend that the topic was neglected between the period of the publication by the HRC of the General Comment $16^{91}$ in 1988 (a document providing interpretative guidance on Article 17 of the ICCPR) and the issue of two seminal Special Rapporteurs' reports in 2009 and 2013. ${ }^{92}$ The first of these - by the Special Rapporteur on the promotion and protection of human rights and fundamental freedoms while countering terrorism, Martin Scheinin $^{93}$ - discussed a number of legal and policy aspects arising from states' communication interception activities. The second - authored by the Special

88 CoE, European Convention for the Protection of Human Rights and Fundamental Freedoms amended by Protocols Nos 11 and 14 (4 November 1950) (European Convention on Human Rights) Art 8 ('ECHR').

89 Organization of American States, The American Convention on Human Rights (The Pact of San José, Costa Rica) (entered into force 18 July 1978) Art 11 ('ACHR').

90 UNHRC, 'Welcome to Human Rights Council', www.ohchr.org/en/hrbodies/ hrc/pages/aboutcouncil.aspx.

91 UNHRC, 'CCPR General Comment No. 16: Article 17 (Right to Privacy). The Right to Respect of Privacy, Family, Home and Correspondence, and Protection of Honour and Reputation' (8 April 1988) UN Doc HRI/Gen/1/Rev.9 (Vol 1) ('General Comment 16').

92 Carly Nyst and Tomaso Falchetta, 'The Right to Privacy in the Digital Age' (2017) Journal of Human Rights Practice 104-18 ('Nyst and Falchetta').

93 UNHRC, 'Report of the Special Rapporteur on the Promotion and Protection of Human Rights and Fundamental Freedoms while Countering Terrorism, Martin Scheinin' (28 December 2009) UN Doc A/HRC/13/37. 
Rapporteur on the promotion and protection of the right to freedom of opinion and expression, Frank La Rue - brought into sharp focus the effects of counterterrorism policies on the right to privacy and the impact of mass surveillance technologies on this and related rights (including the freedom of expression). ${ }^{94}$

In the years that followed and largely as a result of the 2013 Snowden exposures, the right to privacy in the digital age was pushed to the top of the policy agenda and became the focus of a number of UNGA and Human Rights Council Resolutions. ${ }^{95}$ On 18 December 2013, the UNGA adopted by consensus a Resolution on the right to privacy in the digital age (Resolution 68/167), ${ }^{96}$ expressing deep concerns over the negative impact of surveillance and communications interception on human rights. Crucially, the UNGA affirmed that the same rights that people have offline must also be protected online and called upon all states to respect and protect the right to privacy of digital communications. ${ }^{97}$ In addition, the Resolution requested the OHCHR to:

submit a report on the protection and promotion of the right to privacy in the context of domestic and extraterritorial surveillance and/or the interception of digital communications and the collection of personal data including on the mass scale to the Human Rights Council. ${ }^{98}$

The resultant 2014 OHCHR report, titled 'The Right to Privacy in the Digital Age', ${ }^{99}$ made a significant contribution and impact, as it not only confirmed that government mass surveillance is 'emerging as a dangerous habit rather than an exceptional measure', but also pointed out some alarming gaps in the implementation of the international legal framework governing these issues. ${ }^{100}$ It is thus widely regarded as 'the yardstick against which to assess States' compliance with their human rights obligations in the context of surveillance' ${ }^{101}$ These developments have been further enhanced by the Human Rights

94 UNHRC, 'Report of the Special Rapporteur on the Promotion and Protection of the Right to Freedom of Opinion and Expression, Frank La Rue' (17 April 2013) UN Doc A/HRC/23/40.

95 UNGA Resolution, 'The Right to Privacy in the Digital Age' (21 January 2014) UN Doc A/Res/68/167 ('A/Res/68/167'); see also UNGA Resolution, 'The Right to Privacy in the Digital Age' (10 February 2015) A/Res/69/166 ('A/Res/69/166'); UNGA Resolution, 'The Right to Privacy in the Digital Age' (19 December 2016) UN Doc A/Res/71/199 ('A/Res/71/199'); UNHRC Resolution, 'The Right to Privacy in the Digital Age' (26 March 2015) UN Doc A/HRC/Res/28/16 ('A/HRC/Res/28/16').

96 A/Res/68/167 ibid.

$97 \mathrm{~A} / \operatorname{Res} / 68 / 167$ ibid; see also A/Res/69/166 and A/Res/71/199 (n 95).

$98 \quad \mathrm{~A} / \mathrm{Res} / 68 / 167$ ibid para 5.

$99 \mathrm{~A} / \mathrm{HRC} / 27 / 37$ (n 26).

100 Ibid.

101 Nyst and Falchetta (n 92) 108. 
Council's adoption of Resolution 28/16 ${ }^{102}$ establishing a dedicated UN special procedures mandate on the right to privacy - that is, the office of the Special Rapporteur on the right to privacy. ${ }^{103}$ The mandate holder is appointed for three years and tasked, among other responsibilities, with reporting on alleged violations on the right to privacy, including in connection with the challenges arising from new technologies. ${ }^{104}$

The HRC has also been closely scrutinizing governments' compliance with the right to privacy under Article 17 of the ICCPR. In concluding observations on Canada, ${ }^{105}$ France, ${ }^{106}$ Namibia, ${ }^{107}$ New Zealand, ${ }^{108}$ Rwanda, ${ }^{109}$ South Africa, ${ }^{110}$ Sweden, ${ }^{111}$ the US ${ }^{112}$ and the UK, ${ }^{113}$ among others, the HRC emphasized its concerns in relation to states' legal regimes allowing for mass interception of communication and the lack of sufficient safeguards against arbitrary interference with the right to privacy. ${ }^{114}$

Also worthy of note are the efforts of the international community in the field of information and communications technology (ICT) in the context of cyber security. Developments in ICT have been on the UN agenda since Russia's introduction in 1998 of a draft resolution on this subject in the First Committee of the UNGA, adopted without a vote as Resolution 53/70. ${ }^{115}$ On

$102 \mathrm{~A} / \mathrm{HRC} / \operatorname{Res} / 28 / 16$ (n 95).

103 UNHRC, 'Special Rapporteur on the Right to Privacy', www.ohchr.org/en/ issues/privacy/sr/pages/srprivacyindex.aspx.The current mandate holder is Professor Joseph Cannataci of Malta.

104 Ibid.

105 UNHRC, 'Concluding Observations on the Sixth Periodic Report of Canada' (20 July 2015) UN Doc CCPR/C/CAN/CO/6.

106 UNHRC, 'Concluding Observations on the Fifth Periodic Report of France' (17 August 2015) UN Doc CCPR/C/FRA/CO/5.

107 UNHRC, 'Concluding Observations on the Second Report of Namibia' (23 August 2016) UN Doc CCPR/C/NAM/CO/2.

108 UNHRC, 'Concluding Observations on the Sixth Periodic Report of New Zealand' (28 April 2016) UN Doc CCCPR/C/NZL/CO/6.

109 UNHRC, 'Concluding Observations on the Fourth Periodic Report of Rwanda' (2 May 2016) UN Doc CCPR/C/RWA/CO/4.

110 UNHRC, 'Concluding Observations on the Initial Report of South Africa' (27 April 2016) UN Doc CCPR/C/ZAF/CO/1.

111 Concluding Observations, Sweden (n 78).

112 UNHRC, "Concluding Observations on the Fourth Periodic Report of the United States of America' (23 April 2014) UN Doc CCPR/C/USA/CO/4 ('Concluding Observations, US').

113 Concluding Observations, United Kingdom (n 78).

114 See, for example, Concluding Observations, UK ibid para 24 and Concluding Observations, US (n 112) para 22.

115 UNGA Resolution, 'Developments in the Field of Information and Telecommunications in the Context of International Security' (4 December 1998) UN Doc A/RES/53/70. 
this basis, five UN Groups of Governmental Experts (GGEs) have been convened to examine existing and potential threats in the cyber sphere and possible cooperative measures to address them. ${ }^{116}$ One of the main achievements of this collaboration was a broad agreement reached by the 2013 GGE that international law - and in particular, the Charter of the United Nations ${ }^{117}$ - applies in cyberspace. ${ }^{118}$ This was followed by the 2015 GGE consensus report, ${ }^{119}$ stipulating numerous non-legally binding norms along with confidence-building measures. ${ }^{120}$ Framed as 11 recommendations (Recommendations 13(a)-(k)), these voluntary non-legally binding rules and principles of responsible state behaviour are aimed at promoting an open secure, stable, accessible and peaceful ICT environment. ${ }^{121}$ In particular, in Recommendation 13(e), the GGE agreed that states, in ensuring the secure use of ICT, should respect human rights and guarantee their full protection, including the right to privacy and freedom of expression. ${ }^{122}$

\subsection{The Right to Privacy in the Digital Age outside of the UN}

Numerous efforts have also been made outside of the UN, which have contributed to the global discussion on the relationship between states' use of ICT and human rights protection. These include a number of initiatives at the multi-stakeholder level, involving intergovernmental organizations, private industry and civil society, together with a valuable contribution from academia.

Thus, at the multi-stakeholder level, the 2014 Statement from the Global Multistakeholder Meeting on the Future of Internet Governance

116 UN Office for Disarmament Affairs, 'Fact Sheet. Developments in the Field of Information and Telecommunications in the Context of International Security' (January 2019), www.un.org/disarmament/ict-security/.

117 UN, Charter of the United Nations (24 October 1945) 1 UNTS XVI ('UN Charter').

118 UNGA, Group of Government Experts on Developments in the Field of Information and Telecommunications in the Context of International Security (24 June 2013) UN Doc A/68/98*.

119 UNGA, 'Group of Governmental Experts on Developments in the Field of Information and Telecommunications in the Context of International Security' (22 July 2015) UN Doc A/70/174.

${ }_{120}$ For more details in relation to the UN GGE process, see Chapter 7, section 4.

121 A/70/174 (n 119) paras 13 (a)-(k).

122 Ibid. For the interpretation of the GGE Recommendations 13(a)-(k), see UN Office for Disarmament Affairs, Voluntary, Non-binding Norms for Responsible State Behaviour in the Use of Information and Communications Technology. A Commentary (UN Office for Disarmament Affairs, 2017). 
('NETmundial') ${ }^{123}$ expressly acknowledged the need for human rights to underpin Internet governance, ${ }^{124}$ including the right to privacy. According to the NETmundial Statement:

The right to privacy must be protected. This includes not being subject to arbitrary or unlawful surveillance, collection, treatment and use of personal data. The right to the protection of the law against such interference should be ensured. Procedures, practices and legislation regarding the surveillance of communications, their interception and collection of personal data, including mass surveillance, interception and collection, should be reviewed, with a view to upholding the right to privacy by ensuring the full and effective implementation of all obligations under international human rights law. ${ }^{125}$

Intergovernmental cooperation saw the introduction in 2013 of a set of guidelines governing the protection of privacy and transborder data flows by the Organization for Economic Co-operation and Development. ${ }^{126}$ The contribution from civil society groups, industry and international experts in communications surveillance has helped to further explore and define how the right to privacy applies to digital interception and collection of communications. Of particular note in this regard are the International Principles on the Application of Human Rights to Communications Surveillance, ${ }^{127}$ which articulate a number of guiding principles to facilitate the protection of this right in the digital age in the context of increased state surveillance.

In tandem with the diplomatic processes at the UN and the range of voluntary norms and recommendations made outside that organization, a group of legal scholars embarked on a project to elaborate how international law applies in cyberspace. The work commenced under the auspices of NATO's Cooperative Cyber Defence Centre of Excellence initially resulted in the Tallinn Manual

123 Global Multistakeholder Meeting on the Future of Internet Governance, 'NETmundial Multistakeholder Statement' (24 April 2014) ('NETmundial Statement').

124 The term 'Internet governance' was first introduced in the 1980s and is defined by the UN Working Group on Internet Governance as ' $[\mathrm{t}]$ he development and application by governments, the private sector and civil society, in their respective roles, of shared principles, norms, rules, decision making procedures and programmes that shape the evolution and use of the internet' - see UN Report of the Working Group on Internet Governance (2005), www.wgig.org/docs/WGIGREPORT.pdf.

125 NETmundial Statement (n 123) para 1 'Internet Governance Principles'.

126 Organization for Economic Co-operation and Development, Guidelines Governing the Protection of Privacy and Transborder Flows of Personal Data, Recommendation of the Council Concerning Guidelines Governing the Protection of Transborder Flows of Personal Data, C(80)58/FINAL as amended on 11 July 2013 by C(2013)79; see 'Annex. Guidelines Governing the Protection of Privacy and Transborder Flow of Personal Data. Part II' paras 7-14.

127 Necessary and Proportionate (n 28). 
on the International Law Applicable to Cyber Warfare, ${ }^{128}$ published in 2013, which focused on the application of jus ad bellum and jus in bello to cyber conflict. This volume was then superseded by the Tallinn Manual 2.0 on the International Law Applicable to Cyber Operations, ${ }^{129}$ which, in addition, analysed the applicability of international law to cyber operations that fall below the 'use of force' threshold. To date, the Manuals are the most comprehensive articulation of how international law - including human rights law ${ }^{130}$ - applies to cyberspace and cyber operations.

\section{MASS SURVEILLANCE AS CONTINUING STATE PRACTICE}

Mass surveillance and privacy issues were the subject of fierce debate in the aftermath of the Snowden disclosures. However, seven years on, these concerns have almost disappeared from open public debate and reporting, despite an overwhelming majority of states around the globe continuing to routinely engage in various methods of unrestrained interception and collection of communications. Thus, according to Boundaries of Law $w^{131}$ - a study conducted under the auspices of the University of Cambridge - mass generalized surveillance is an exponential and indiscriminate practice, which goes beyond the Five Eyes' intelligence gathering operations. The survey, carried out between 2013-17, considered a diverse selection of 14 countries across five continents to attest to this ongoing and widespread state practice. The document reported on a number of issues, including mass surveillance being undertaken either without any legal basis or on the premise of secret and opaque laws, ${ }^{132}$ allowing 'governments to interfere arbitrarily with the right to confidentiality of communications of hundreds of millions of people worldwide by collecting data in bulk without proven cause for suspicion" ${ }^{133}$ - meaning that

128 Michael N Schmitt (ed), Tallinn Manual on the International Law Applicable to Cyber Warfare (Cambridge University Press, 2013).

129 Michael N Schmitt (ed), Tallinn Manual 2.0 on the International Law Applicable to Cyber Operations (Cambridge University Press, 2017) ('Tallinn Manual 2.0').

130 See ibid Chapter 6.

131 Douwe Korff, Ben Wagner, Julia Powles, Renata Avila and Ulf Buermeyer, Boundaries of Law: Exploring Transparency, Accountability and Oversight of Government Surveillance Regimes (University of Cambridge Faculty of Law, 2013). The study surveyed the United Kingdom, the United States, Colombia, the Democratic Republic of the Congo, Egypt, France, Germany, India, Kenya, Myanmar, Pakistan, Russia, South Africa and Turkey.

132 Ibid.

133 Ibid 8. 
the surveillance is mostly conducted illegally. ${ }^{134}$ Furthermore, in most of the countries surveyed, the intelligence community can demand direct access to telecommunications infrastructure through a 'back door'135 and thus intercept both content and metadata. ${ }^{136}$ In addition, the most commonly invoked ground for the interference with privacy - that is, 'national security' - is so broadly defined in most domestic legal instruments that it is meaningless. ${ }^{137}$ Furthermore, the document reported that such intelligence collection rarely requires judicial authorization, instead being approved in many countries by the prime minister, a minister, a senior official, the police, the military and intelligence services, or any authorized agency; ${ }^{138}$ while oversight systems are often non-existent or ineffective because they are not independent. ${ }^{139}$ There is also a trend towards countries conducting surveillance under semi-permanent states of quasi-emergency. ${ }^{140}$ The report's overall tenor is therefore that the right to privacy is guaranteed in principle, but not respected in practice. ${ }^{141}$

That mass surveillance is now a permanent feature of everyday life has also been confirmed by the 2019 report of the Special Rapporteur on the promotion and protection of the right to freedom of opinion and expression referred to other types of surveillance enabled by a wider range of technologies to gain surreptitious access to digital communications, work product, browsing data, research and location history, together with individuals' online and offline activities. ${ }^{142}$ These include affect recognition (a technology that seeks to infer a person's feelings, emotions or intentions from facial expression); deep packet inspection (this enables the monitoring, analysis and redirection of traffic passing through communications and Internet networks, which may lead users to sites infected with malware and block them from accessing certain websites); and social engineering practices (ie, strategies to lure a target into unwittingly downloading malware on their devices, to spy on their communications).

134 Ibid.

135 Ibid.

136 Ibid.

137 Ibid.

138 Ibid.

139 Ibid.

140 Ibid.

141 Ibid.

142 UNHRC, 'Surveillance and Human Rights. Report of the Special Rapporteur on the Promotion and Protection of the Right to Freedom of Opinion and Expression' (28 May 2019) UN Doc A/HRC/41/35. 


\section{THE SURVEILLANCE, SECURITY AND PRIVACY PARADOX}

Drawing on this thumbnail sketch, it can be said that surveillance, security and privacy present a difficult paradox - perhaps best illustrated by the seemingly competing policy strands at both the UN and domestic levels, which ostensibly pull in opposite directions.

Thus, for a number of decades the UN has expressed a 'strong condemnation of terrorism in all its forms and manifestations ... as it constitutes one of the most serious threats to international peace and security'. ${ }^{143}$ To this end, the $\mathrm{UN}$ has urged states to take action to prevent and combat terrorism, including by 'intensifying cooperation, as appropriate, in exchanging timely and accurate information concerning the prevention and combating of terrorism'. ${ }^{144}$ Concurrently, however, it has also recognized that international cooperation must comply with international human rights law. ${ }^{145}$ This has been emphasized on numerous occasions, including in the UNGA Resolution on the right to privacy in the digital age (Resolution 68/167), which noted that:

the rapid pace of technological development ... enhances the capacity of governments, companies and individuals to undertake surveillance, interception and data collection, which may violate or abuse human rights, in particular the right to privacy, as set out in article 12 of the Universal Declaration of Human Rights and article 17 of the International Covenant on Civil and Political Rights. ${ }^{146}$

Domestically, a small group of countries have begun to 'modernize' or 'overhaul' their surveillance laws by putting their bulk powers of interception and data collection on a statutory footing. The impetus for this seems to have derived from the intensity of the terrorist attacks that ensued in quick succession between 2015-19, including those in Paris, ${ }^{147}$ Brussels, ${ }^{148}$ Orlando,

143 A/Res/60/288 (n 58) para 2.
144 Ibid Plan of Action point 4.
Ibid Plan of Action point 3 .
146 A/Res/68/167 (n 95) para 4 .
147 International Business Times, 'Europe Terrorist Attacks 2016: Timeline of

147 International Business Times, 'Europe Terrorist Attacks 2016: Timeline of
Bombings and Terror Threats Before Brussels' (24 April 2016). Paris was subject to two terrorist attacks that year, in January and November.

148 Ibid. 
Florida, ${ }^{149}$ London $^{150}$ and Sri Lanka. ${ }^{151}$ A number of nations have responded by adopting more draconian surveillance legislation justifying the enactment of these measures on national security grounds. Examples include the UK Investigatory Powers Act 2016; ${ }^{152}$ the US Cybersecurity Sharing Act 2015; ${ }^{153}$ the French Intelligence Act 2015, ${ }^{154}$ and the German Act on the Federal Intelligence Service 2016. ${ }^{155}$ The introduction of these statutes was accompanied by heated public debate centred on the need to reconcile two purportedly opposing paradigms: that is, individuals' entitlement to privacy ${ }^{156}$ and the state's right to restrict it on the grounds of national security in order to provide the police and intelligence agencies with access to information necessary to conduct their investigations. ${ }^{157}$ In the context of this dichotomy, achieving a balance between the need for security and the protection of the privacy of individuals is seen as essential to a free society, yet these values are often presented and perceived as opposites. As a result, any attempt to accommodate the need for these seemingly competing rights is highly challenging in an era of digitalization and continued threats to collective security, at both the domestic and global levels. This complexity seems to be magnified by the view that security can be achieved only if individuals and societies resign themselves to the fact that states must conduct mass surveillance in order to discharge their obligations to keep their citizens safe and in that sense, trade off their fundamental rights, ultimately achieving greater safety. This is the stance adopted by some government officials - including the former UK Foreign Secretary William Hague, who insisted, in his 2013 response to the growing concerns

149 The Guardian, 'Orlando: Obama Condemns "Acts of Terror" After Worst Mass Shooting in US History' (13 June 2016). The June 2016 shooting in Orlando, Florida was described by the then US President Barak Obama as 'the most deadly shooting in American history'.

150 BBC News, 'London Attack: Seven Killed in Vehicle and Stabbing Incidents' (2 June 2017).

151 BBC News, 'Sri Lanka Attacks: The Family Networks Behind the Bombings' (11 May 2019).

152 Investigatory Powers Act 2016 c 25.

153 CISA S.2588 $\left[113^{\text {th }}\right.$ Congress $]$, S $754\left[114^{\text {th }}\right.$ Congress $]$.

154 French Intelligence Act 2015 (Law 2015-912).

155 German Act on the Federal Intelligence Service 2016 ('BND Act').

156 The Guardian, 'Extreme Surveillance Becomes UK Law with Barely a Whimper' (19 November 2016). In that article, The Guardian quoted the statement made by Edward Snowden, who on 19 November 2016 tweeted that 'the UK has just legitimised the most extreme surveillance in the history of western democracy. It goes further than many autocracies'.

157 Paul Bernal, 'Data Gathering, Surveillance and Human Rights: Recasting the Debate' (2016) Journal of Cyber Policy 243-64. 
over the US PRISM program, that 'if you have nothing to hide you have nothing to fear', ${ }^{158}$ reiterating a phrase first popularized by Joseph Goebbels.

There can be no doubt that at the domestic level, a decisive trend can be discerned towards achieving greater security by means of mass surveillance of both foreign and domestic communication. This pronounced shift towards greater securitization ${ }^{159}$ adopted by many states in the second decade of the twenty-first century indicates that there is little prospect of these practices being abandoned. They are thus of concern to international law. To this end, following the Snowden disclosures, the UN institutions and mandate holders have begun to recognize that the cost to civil liberties might ultimately far outstrip the gains realized by the policy of achieving relative freedom from dangers or threats to security. This is because unrestrained surveillance abrogates the rule of law and thus poses a serious challenge to core human rights, including the right to privacy. ${ }^{160}$ On these bases, therefore, the 'surveillance, security and privacy paradox' can be framed in terms of a cost-benefit analysis - that is, a process of estimating the costs involved in attaining global and domestic security through mass surveillance and the possible benefits to be derived from this for individual nations and for the international community.

\section{THE AIMS OF THIS BOOK}

As already observed, the cyber surveillance, security and privacy paradox is replete with competing interests and thereby represents a challenge not only to individual states, but also to the international community as a whole - and by extension, to international law. Therefore, it must be addressed as a global problem. Accordingly, the primary purpose of this book is to show that there is a need to establish common international law standards to address state sponsored cyber surveillance. Such a legal framework, regulating the working methods of intelligence and law enforcement agencies, should be put into place in order, among other things, to impose minimum benchmarks for transparency, accountability and oversight in relation to both intelligence gathering and sharing. At present, there are no specific rules of international law - in the form of either an international treaty or customary international law - that directly address this problem.

158 The Telegraph, 'William Hague: British Public 'Have Nothing to Fear' From US Spies' (9 June 2013).

159 Bary Buzan et al, Security: A New Framework (Lynne Rienner Publishers, 1998) 24. In the context of international relations, an issue is 'securitized' when it 'is presented as an existential threat, requiring emergency measures and justifying actions outside the normal bounds of political procedures'.

160 See, for example, $\mathrm{A} / \mathrm{HRC} / 27 / 37$ (n 26). 
To this end, the aim of this book is threefold. First, it ascertains how existing international human rights law applies to state sponsored cyber surveillance, focusing on the right to privacy of communications. To this end, it identifies the sources of this right and examines whether online privacy has attained customary international law status. Second, it engages with the question of whether existing treaty rules that aim to protect it are adequate to meet the challenges posed by ubiquitous mass surveillance, or whether there is a need for a specific international legal framework regulating these activities. In this context, the book proposes a legal taxonomy that reflects various state intelligence operations that have emerged in recent years, which can be broadly divided into three categories: (1) cyber espionage; (2) cyber surveillance; and (3) cyber electoral interference. Based on this differentiation, the book's third and final aim is to evaluate the prospects of a multilateral surveillance treaty being adopted at an international and/or regional level, acknowledging the fact that any success in this regard is dependent on states' vested interests and political will. With this in mind, the book considers other methods of controlling mass surveillance - in particular, states being guided by cyber-specific non-legally binding norms for responsible behaviour in the digital domain.

This book predominantly scrutinizes the relationship between the individual's right to privacy of communications and state cyber surveillance. It assesses how the existing rules laid down in Article 17 of the ICCPR, Article 8 of the ECHR and Article 11 of the ACHR apply to these activities. The book's focus on these legal instruments stems from the fact that most countries, including the Five Eyes partners, are signatories to these treaties, although, as will be discussed later, the US does not regard itself as being bound by the ICCPR in relation to acts conducted outside of its territory. Nevertheless, most governments are under a legal duty both to protect and to respect individuals' right to privacy as stipulated and interpreted by the relevant judicial organs. Related to this right is a body of rules pertaining to the protection of personal data. ${ }^{161}$ However, a detailed analysis of this area of law is beyond the scope of this book. This is because data protection law has grown exponentially and is increasingly recognized as a distinct human right, ${ }^{162}$ thus warranting detailed and separate analysis. Notwithstanding, frequent references are made to the

161 See Kriangsak Kittichaisaree, Public International Law in Cyberspace (Springer, 2017) 59. Data protection and the right to privacy may be distinguished because '[t]he former regulates the processing of an individual's personal data - be it private or non-private, whereas the latter protects an individual against intrusions into his private sphere'.

162 See, for example, Monika Zalnieriute, 'An International Constitutional Moment for Data Privacy in the Times of Mass-Surveillance' (2015) 23 International Journal of Law and Information Technology 99-133. 
EU data protection regime and to a number of landmark decisions of the Court of Justice of the European Union (CJEU) relating to the issues of data retention, cross-border transfers and mass interception of communications.

The book is concerned with states, as against non-state actors, examining their obligations for human rights protection in cyberspace, since under international law the former are the main parties to be considered responsible for wrongful acts or omissions, including violations of human rights. ${ }^{163}$ A consideration of the role played by the latter - principally the private sector, comprising powerful Internet companies - has been deliberately omitted from its scope, since their involvement in surveillance and the responsibilities that this creates warrant a discrete legal analysis.

The Snowden exposures concentrated attention on the Five Eyes. Although global digital surveillance goes far beyond these states' involvement, the book makes frequent references to that alliance, with particular regard paid to US and UK laws and practice. This is because these countries are not only considered to be among the most technologically advanced in the world, giving them a dominant position in the cyber domain, ${ }^{164}$ but also due to their unparalleled surveillance capabilities, together with the domination of US corporations of the provision of Internet services globally.

\section{THE SCOPE OF THIS BOOK}

To achieve its stated aims, this book takes as its starting point the positioning of mass surveillance within the security-privacy trade-off, according to which greater security can be achieved only by sacrificing some fundamental freedoms, including privacy. This issue has been addressed in this introductory chapter, which conceives of the problem in terms of 'cost-benefit' analysis and contends that it is misleading to suggest that security can be achieved only at the cost of forfeiting fundamental rights.

The book then situates state cyber surveillance within international law discourse pertaining to peacetime cyber espionage, to explore how these activities are similar and how they differ. The rationale for such delineation is based on the emerging state practice, which dictates a need for the adoption of a more granular distinction that recognizes different types of intelligence-gathering

163 See International Law Commission, 'Draft Articles on Responsibility of States for Internationally Wrongful Acts with Commentary' (2001) Yearbook of the International Law Commission, General Commentary para 1.

164 See Tony Morbin, 'UK and US Sign Military Cyber Accord to Dominate Cyber Domain-With Help From Business', Cyber Security Source (23 October 2018), www .scmagazineuk.com/uk-us-sign-military-cyber-accord-dominate-cyber-domain-help -business/article/1496952. 
operations in cyberspace. This is the subject for consideration in Chapter 2, which separates these activities into three distinct categories, namely, cyber espionage, cyber surveillance and cyber electoral interference, to gain an understanding of how international law applies to each of them.

Chapter 3 outlines the value of privacy both as a social norm and as an international human right. To this end, it discusses whether the right to online privacy - as proclaimed by the UNGA and the Human Rights Council Resolutions ${ }^{165}$ - can be considered as a customary international law rule, thus constituting a separate source of rights. Having concluded that this cannot yet be said with any certainty, the chapter concludes that international treaties are the main basis of states' obligations to protect the privacy of communications.

Chapter 4 proceeds to analyse the scope of states' obligations under the ICCPR, the ECHR and the ACHR. Since current practice confirms that nations habitually undertake mass surveillance outside their territories - often either without a specific legal basis or pursuant to legislation that differentiates on the grounds of nationality (or the nature of communications) - this chapter argues that such laws breach the right to equal treatment and non-discrimination. Furthermore, it asserts that states' human rights obligations in the context of extraterritorial surveillance of foreign communications are engaged when effective control over an individual's rights is being exercised.

Chapter 5 then delineates the ambit of the right to privacy stipulated in the ICCPR, the ECHR and the ACHR, and discusses what constitutes an interference with this right in the context of mass surveillance.

Chapter 6 engages with the principal legal grounds upon which states legitimize interference with the right to privacy, with particular attention paid to the ostensible fragmentation of approaches between the UN human rights bodies, the inter-American human rights organs on the one hand, and the ECtHR on the other.

Chapter 7 considers the feasibility of regulating the working methods of state intelligence and security agencies through a legally binding treaty, positioning this discussion within the broader context of cyber security discourse. Having outlined a number of failed efforts to agree legally binding rules for this domain, including for state surveillance, it examines non-legally binding cyber norms as a means of guiding responsible states' behaviour when engaged in mass surveillance.

165 A/Res/68/167 (n 95); A/Res /69/166 (n 95); A/Res/71/199 (n 95); UNHRC, 'The Promotion, Protection and Enjoyment of Human Rights on the Internet' (16 July 2012) UN Doc A/HRC/Res/20/8; UNHRC, 'The Promotion, Protection and Enjoyment of Human Rights on the Internet' (14 July 2014) UN Doc A/HRC/Res/26/13. 
Chapter 8 offers a summary of findings and considers the future of the right to privacy in the light of developing technologies. It concludes that any process aimed at curtailing the practice of mass cyber surveillance is likely to be incremental at best. 